\title{
Middle Ordovician Aparchitidae and Schmidtellidae: the significance of 'featureless' ostracods
}

\author{
MARK WILLIAMS' \& JEAN M. C. VANNIER ${ }^{2}$ \\ 'Department of Geology, University of Leicester, Leicester, LE1 7RH, UK \\ ${ }^{2}$ Centre des Sciences de la Terre, Université Claude Bernard, Lyon, France
}

\begin{abstract}
Schmidtellidae and Aparchitidae form a common element of North American middle Ordovician ostracod faunas. Characterized by relatively simple morphology with few obvious diagnostic features they are conventionally assigned to the Leiocopa. Their simple morphology has led to numerous species being referred to as 'bag gencra' such as Aparchites or Schmidtella. Aparchitids differ markedly from schmidtellids in the nature and degree of valve overlap, shell thickness and development of dorsal and ventral valve modifications. Schmidtellids may be more closely related to leperditellaceans. Kayina, previously assigned to the leiocope Family Jaanussoniidae and recorded from the middle Ordovician of North America, does not conform to leiocope morphology and is probably a leperditellacean. Aparchitaceans (Aparchitidae and Jaanussoniidae) may represent the root-stock from which the Paraparchitacea evolved later in the Palaeozoic. In North America schmidtellids and aparchitids have potential for middle Ordovician stratigraphic correlation. They co-occur in normal marine shelf depositional environments but were absent from marginal marine depositional settings. J. Micropalaeontol. 14(1): 7-24, April 1995.
\end{abstract}

\section{INTRODUCTION}

Morphologically simple ostracods comprising a bivalved subrounded carapace with gently convex valves, apparently indistinct ventral structures, no sulcation and no dimorphism are commonly documented in monographic studies of North American middle Ordovician ostracods. Often they form significant elements of such ostracod faunas (e.g. Harris, 1957; Kraft, 1962). Because of their simplicity they have inevitably been referred to a small number of genera, classic examples being Aparchites, to which more than a 100 species have been referred (see Kempf, 1986), and Schmidtella. Aparchitid and schmidtellid ostracods are conventionally assigned to the Leiocopa Schallreuter, 1973 (see Williams 1990) which is envisaged to encompass three families: the Aparchitidae Jones (in Chapman), 1901 and the Jaanussoniidae Schallreuter, 1971 which are generally united in the Superfamily Aparchitacea, and the Schmidtellidae Neckaja, 1966.

Utilizing two well preserved North American middle Ordovician ostracod faunas from the Simpson Group of Oklahoma and the Edinburg Formation of Virginia this paper aims to: establish criteria on which relatively featureless schmidtellid and aparchitid ostracods can be identified and distinguished; elucidate the relationships of aparchitid, schmidtellid and jaanussoniid ostracods; and indicate their stratigraphic and palaeoenvironmental significance in the North American middle Ordovician.

\section{GENERAL MORPHOLOGY OF LEIOCOPES}

By comparison with other Palaeozoic ostracods, particularly the majority of palaeocopes, leiocope ostracods generally have very simple carapace morphology. Typical leiocopes (Fig. 1) have inequally sized gently convex valves and in lateral view overall carapace shape is generally subcircular or equilateral. Leiocopes are characterized by valve asymmetry, manifested by inequally sized valves and by ventral or dorsal modifications of one or both of the valves. Morphological features of the Aparchitidae, Schmidtellidae and Jaanussoniidae are summarized as follows.

Aparchitidae. (See Swartz, 1969; Schallreuter, 1973; Vannier, 1990; herein Fig. 1 A, D.) In lateral view Aparchitidae typically have a subcircular carapace. Both valves are gently convex and the larger right valve overlaps the left valve. A sulcus or sulcament is absent but a well defined adductor muscle spot is often evident on ornamented valves. Specialized structures are developed on the left or both valves and are usually situated ventrally at the junction between the lateral and ventral valve surfaces (Vannier, 1990, figs 1, 5). These generally consist of ridges, denticles or thickenings on the left valve, and grooves or bends on the right valve. Aparchitidae are widely documented from the Ordovician to Devonian in North America and Europe.

Schmidtellidae. (See Warshauer \& Berdan 1982; Berdan 1988; Fig. 1 B, E) Schmidtellidae are typically subcircular to slightly postplete in lateral view and inequivalved, the left valve overlapping the right valve. They have thick, convex valves often with distinct dorsal umbones and the margins of the lateral surface of valves are generally flattened or furrowed. Most forms are non-sulcate though forms with an internal adductorial ridge are reported. The Schmidtellidae are documented from the Ordovician to Devonian of North America and from the Ordovician of Europe.

Jaanussoniidae. (See Schallreuter 1971; Vannier 1990; Fig. 1 C, F) Jaanussoniidae are preplete to subcircular in lateral outline. Both valves are gently convex and the larger right valve overlaps the left valve. The left valve is 


\section{Aparchitidae}

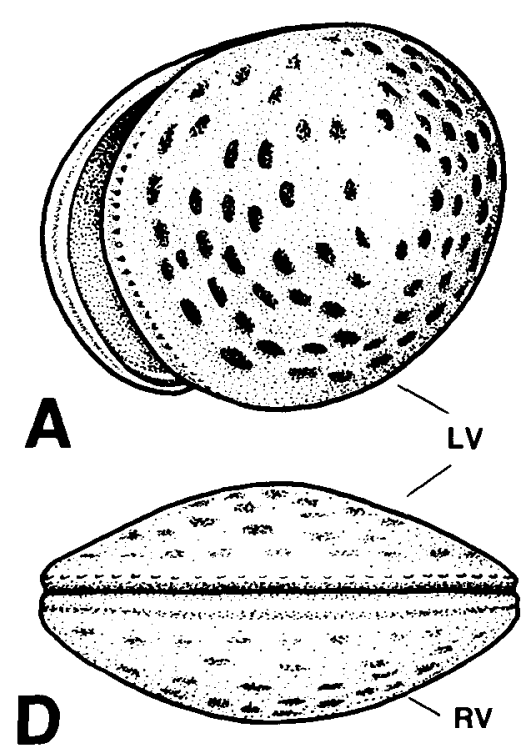

Baltonotella
Schmidtellidae

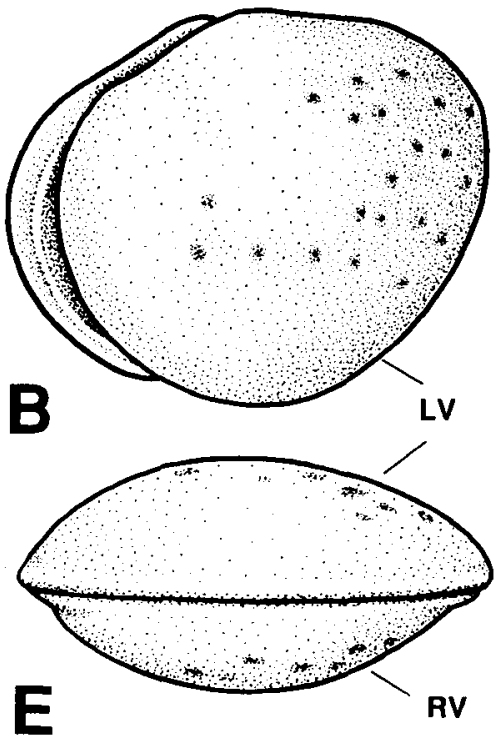

Punctoschmidtella
Jaanussoniidae

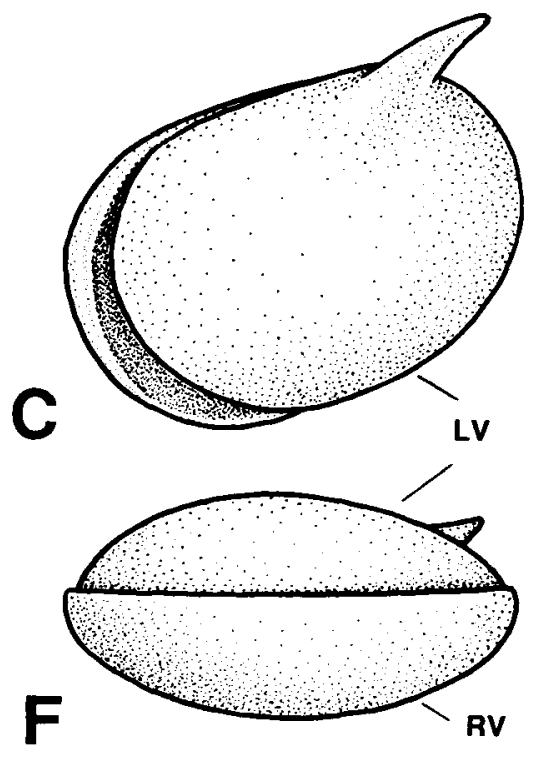

Jaanussonia

Fig. 1. External morphology of a typical aparchitid, schmidtellid and jaanussoniid carapace. Illustrations A, B, C are oblique lateral views; D, $\mathrm{E}, \mathrm{F}$ are ventral views. $\mathrm{LV}$, left valve; $\mathrm{RV}$, right valve.

generally modified dorsally and may have a spine, knob or rounded umbo which is not present on the right valve. Specialized ventral structures are not recorded but some species have a weak internal sulcament. Jaanussoniidae are documented from the Silurian to Devonian of North America and from the Ordovician of Europe.

\section{MATERIAL AND METHODS}

Most of the ostracods studied are from the middle Ordovician Simpson Group of Oklahoma, principally from the Oil Creek and Bromide formations, which contain rich ostracod faunas. The Simpson Group contains a prolific and well documented fossil fauna including trilobites (Shaw, 1974), brachiopods (Cooper, 1956), echinoderms (Sprinkle, 1982), chitinozoans (Grahn \& Miller, 1986), conodonts (Bauer, 1987) and ostracods (Harris, 1931, 1957). The ostracod fauna is amongst the richest recorded from the middle Ordovician of North America with more than 130 species. The stratigraphy (Whiterockian-early Mohawkian, approximately equivalent to the Llanvirn-Caradoc interval in the British Series; see Ross et al., 1982; Sweet, 1984) and palaeoenvironments of the Simpson Group have been well documented (see Decker \& Merritt, 1931; Longman, 1981, 1982). In the Simpson Group palaeocope ostracods are the dominant element of the ostracod fauna in terms of species. However, schmidtellid and aparchitid ostracods form a significant proportion, at least 23 species occuring. The Simpson Group provides an excellent faunal database from which to study these ostracods.
Simpson Group ostracod carapaces (calcareous) were extracted from mudstones which were disaggregated in baths of $10 \%$ hydrogen peroxide, wet sieved, dried and then picked for microfossils. The ostracods often occur as complete carapaces and are relatively robust. Specimens have been thin sectioned in order to evaluate the nature of the valve margin.

In addition to specimens from the Simpson Group, silicified ostracods from the middle Ordovician Edinburg Formation of Virginia have also been included in this study (see Kraft, 1962). Most specimens from the Edinburg Formation occur as fragile individual valves, allowing internal morphology to be examined.

Partly following procedures for the description of species devised for the new Treatise on Invertebrate Paleontology, Paleozoic Ostracoda, morphological features are discussed in sections below: Geometry and general carapace morphology; Domiciliar features; Extradomiciliar features; and Features of the valve margin.

Representative suites of the ostracods described herein are housed in the collections of the Centre des Sciences de la Terre, Université Claude Bernard, Lyon, France and in the Department of Geology, University of Leicester, UK. Repositories for figured specimens are: MCZ, Museum of Comparative Zoology, Harvard University, USA; NHM, Natural History Museum, London, UK; LEIUG, University of Leicester, Geology Department, UK; FSL, Centre des Sciences de la Terre, Université Claude Bernard, Lyon, France; IGR, Institute de Géologie de l'Université Rennes, Rennes, France. 
MORPHOLOGY OF APARCHITIDAE

The major morphological features of aparchitids and schmidtellids from the Simpson Group and Edinburg Formation are illustrated and summarized in Fig. 2 (see also Table 1). Aparchitidae are widely distributed in the North
American middle Ordovician (Fig. 3). In the Simpson Group species belonging to several genera occur, including Baltonotella (Pl. 1; Pl. 4, figs 1, 5, 9, 13, 16-18), Hyperchilarina (Pl. 2, figs 1-3, 5, 6, 8-10; Pl. 4, figs 2, 6, 10), Saccelatia (Pl. 2, figs 11, 12, 14), Bullatella and a species

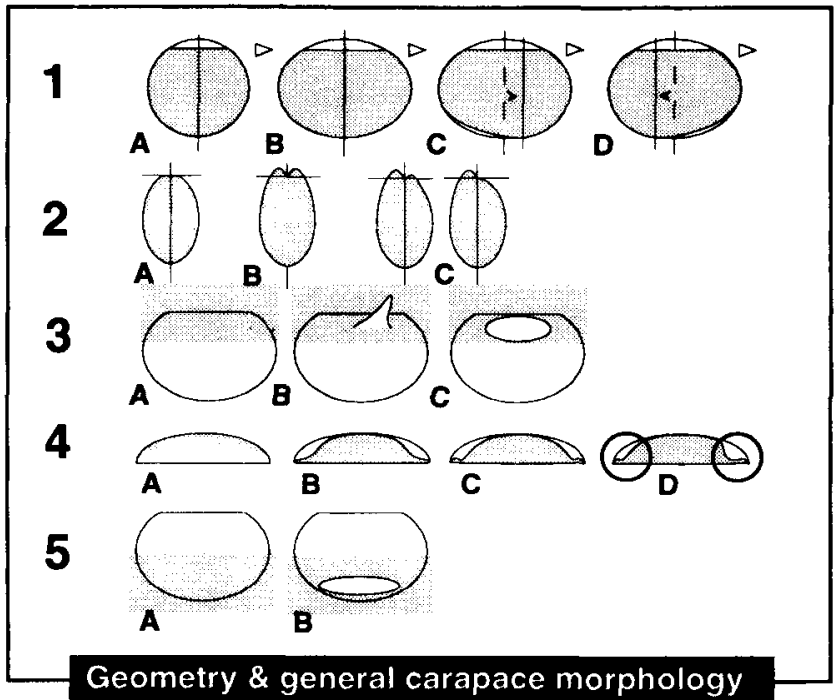

Geometry \& general carapace morphology
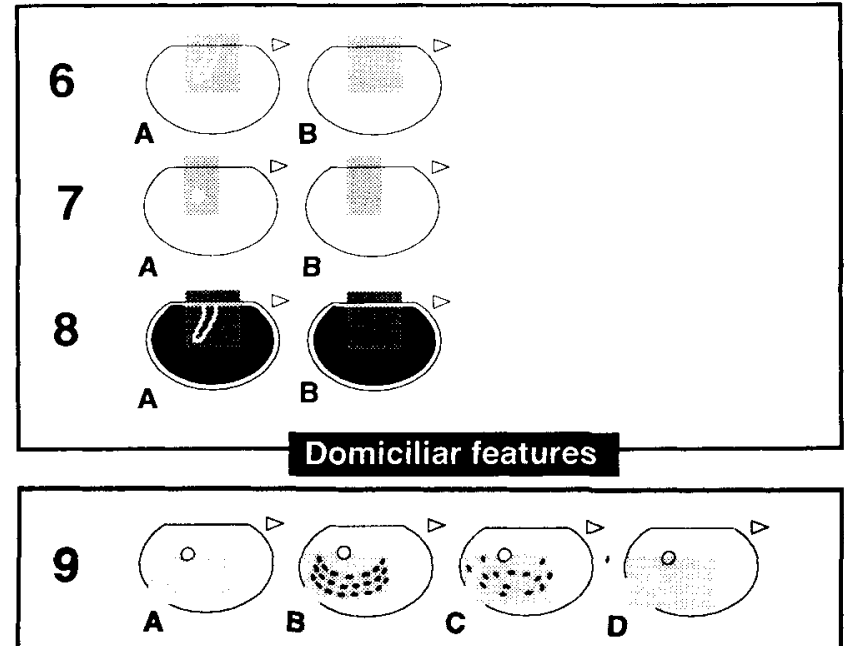

Extradomiciliar features

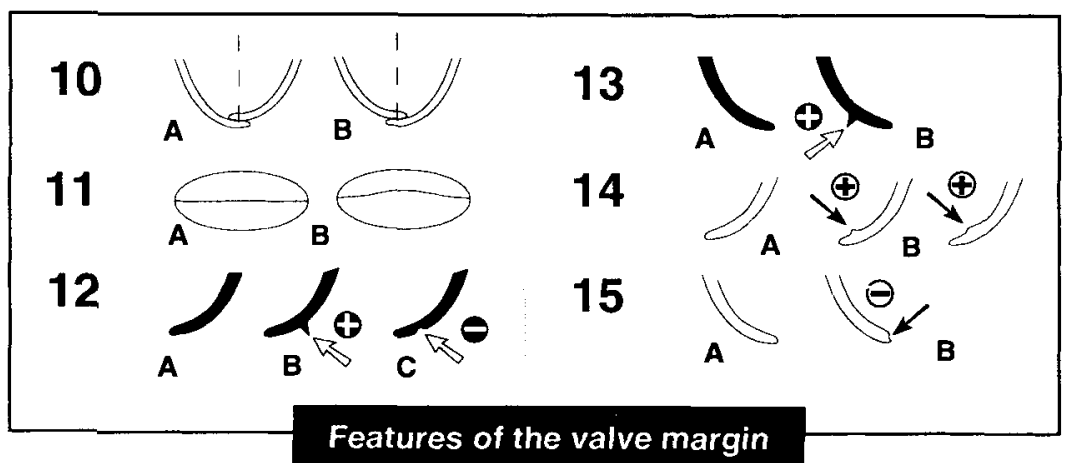

Fig. 2. Morphological features of aparchitid, schmidtellid and jaanussonid ostracod carapaces. See Table 1 for explanation. 


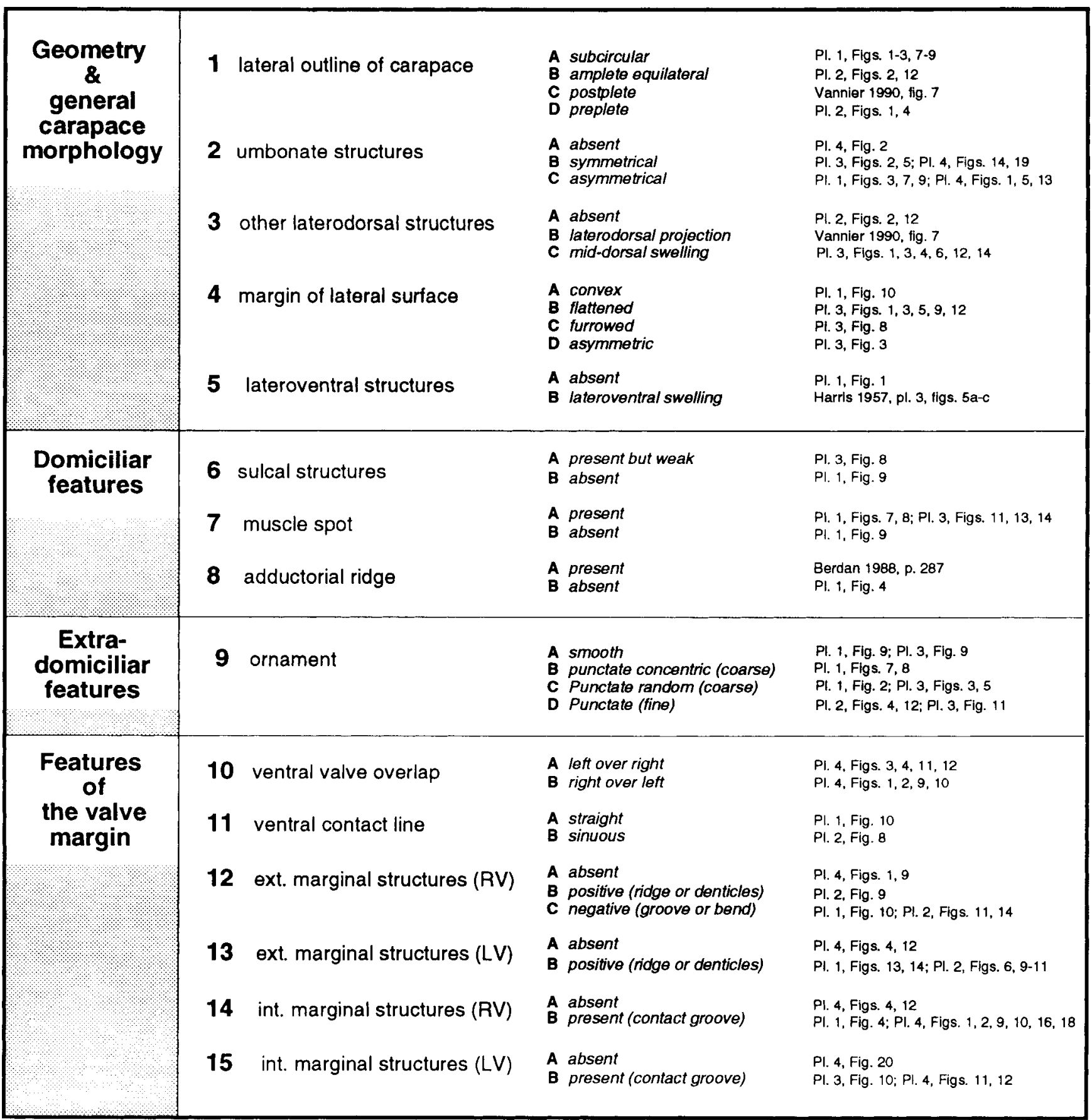

Table 1. Explanation of morphological features illustrated in Fig. 2. Right hand column refers to illustrations in Pls 1-4.

referable to a new genus ('Leperditella' subcygnoides of Harris, 1957; Pl. 2, figs 4, 7, 13). Baltonotella is also a common element of Edinburg Formation ostracod faunas (Pl. 1, figs 1, 4, 9, 11). In both the Simpson Group and the Edinburg Formation large 'populations' of aparchitid species, including juveniles and adults occur.

\section{Geometry and general carapace morphology}

Carapace shape. In lateral view the majority of aparchitids have a subcircular (Pl. 1, figs 1-3, 7-9) or amplete equilateral carapace outline (Pl. 2, figs 2, 12), though the outline is sometimes slightly preplete (Pl. 2, figs 1, 4). From a ventral or dorsal aspect the valves are evenly 


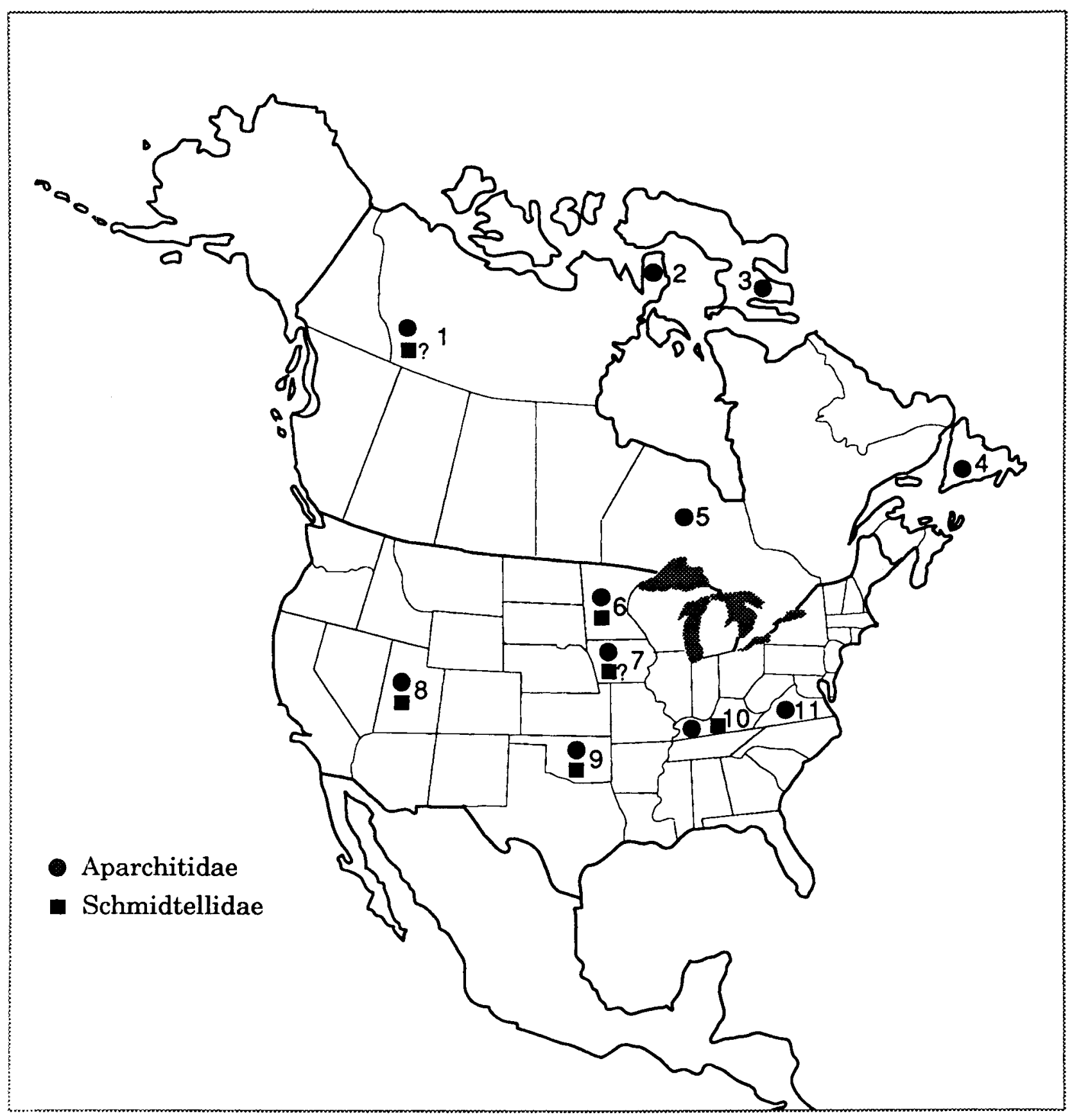

Fig. 3. Distribution of Aparchitidae and Schmidtellidae in the middle Ordovician of North America. 1, District of Mackenzie, NW Territories (Copeland, 1974, 1982); 2, Melville Peninsula, NW Territories (Copeland, 1977); 3, Silliman's Fossil Mount, Baffin Island (Copeland, 1977); 4, Newfoundland (Copeland \& Bolton, 1977); 5, Ontario (Copeland, 1965, 1977); 6, Minnesota (Ulrich, 1894; Kay, 1940; Swain et al., 1961); 7, Iowa (Kay, 1940); 8, Utah (Berdan, 1988); 9, Oklahoma (Harris, 1931, 1957); 10, Kentucky (Warshauer \& Berdan, 1982); 11, Virginia (Kraft, 1962).

convex (ranging from gently to strongly convex) and form a dome shape (Pl. 1, fig. 10; Pl. 2, fig. 8). Rarely the lateral surface of the valves may be more flattened.

Dorsal features. The hinge is straight and typically both valves meet dorsally at the same height (Pl. 2, figs 9, 13;
Pl. 4, fig. 2). However, the smaller left valve can overreach the larger right valve dorsally, a characteristic feature of Baltonotella (Pl. 1, figs 3, 7, 9; Pl. 4, figs 1, 13), or both valves can be umbonate with the hinge lying in a depression. 


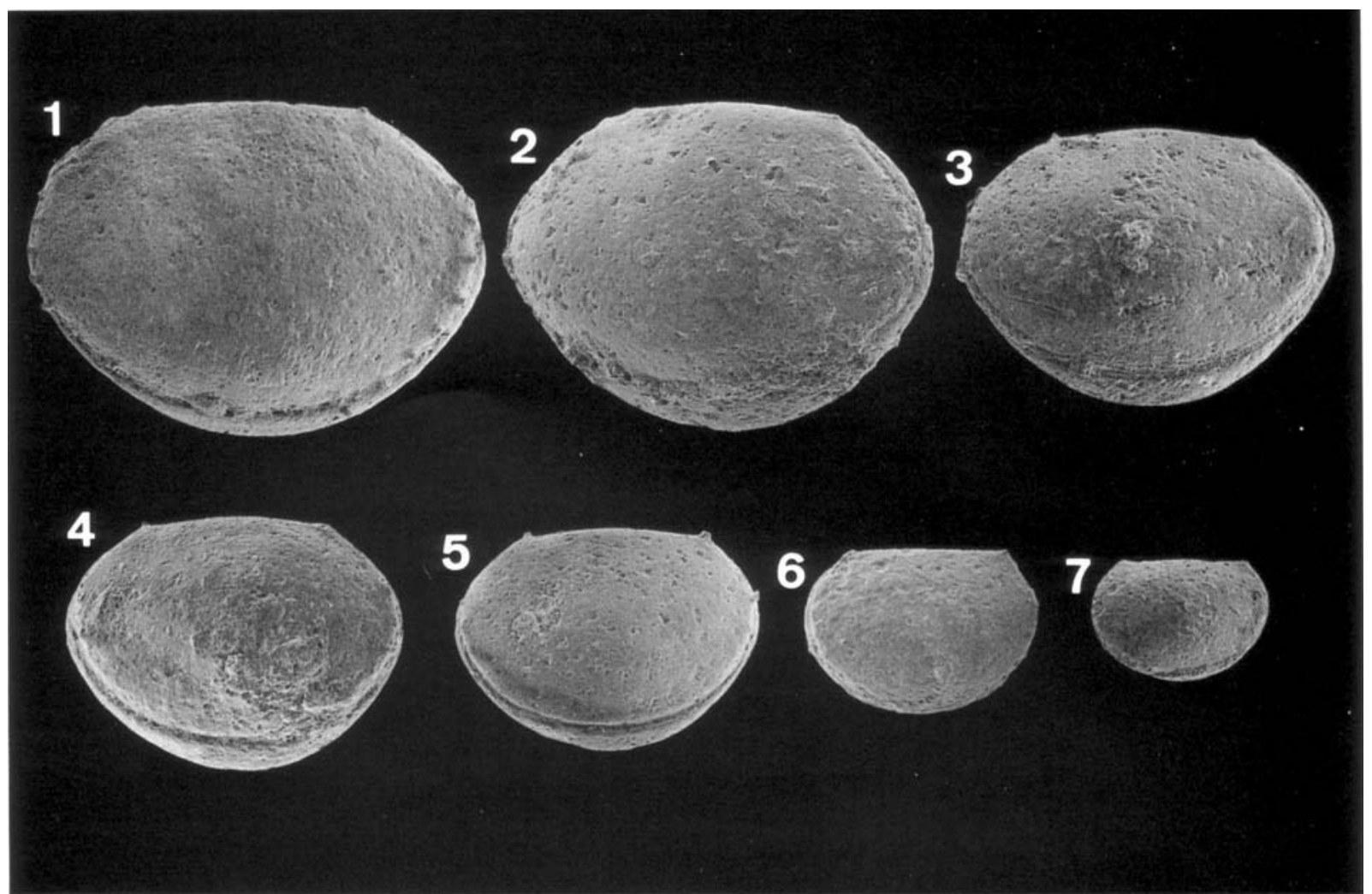

Fig. 4. Ontogeny of Baltonotella parsispinosa (Kraft, 1962). All carapaces from the Bromide Formation, middle Ordovician, Oklahoma, USA. All views are left valve lateral, $\times 32$. Specimen numbers are respectively: 1-4, 6, 7: FSL575056-575061; 5: NHMOS13567.

Ontogeny. With the exception of size increase the general morphology of the carapace does not change considerably during ontogeny (Fig. 4). However, ornament does vary. Ontogenetic studies of Baltonotella circulantis (Harris, 1957) from Oklahoma show that the original figured specimens (Harris, 1957, pl. 6, figs 1a-c) were small unornamented juveniles. Larger specimens (adults and larger juveniles), which are punctate, are identical to Brevidorsa strodescreekensis Warshauer \& Berdan, 1982 (pl. 10, figs 8-15), indicating the synonymy of the two species. Likewise, juveniles and adults of Baltonotella elegans also appear dissimilar when examined without knowledge of ontogeny (see $\mathrm{Pl}$. 1, figs 8, 7; juvenile and adult respectively).

\section{Domiciliar features}

Sulcation and lobation. Aparchitidae have no sulcal or lobal structures. However, a smooth adductorial muscle spot is often discernable (Pl. 1, figs 7,8).

\section{Extradomiciliar features}

Ornament. Ornament is somewhat dependent on preservational state and ontogeny. The majority of aparchitid ostracods in the middle Ordovician of North America have smooth valves or fine punctation (see Swain et al., 1961; Kraft, 1962; Pl. 2, figs 4, 12). Coarse punctation is also common. The punctae may be arranged concentrically around a central smooth (adductor muscle) spot (Pl. 1, figs 7,8 ) or can be more randomly distributed (PI. 1, fig.

\section{Explanation of Plate 1}

Aparchitidae. All specimens from the Simpson Group, middle Ordovician, Oklahoma, USA, except Figs 1, 4, 9 and 11 which are from the Edinburg Formation, middle Ordovician, Virginia, USA. Fig. 1. Baltonotella circulantis (Harris, 1957). Carapace, left valve lateral view, $\times 42$; LEIUG112089. Edinburg Formation. Figs 2, 5. Baltonotella circulantis (Harris, 1957). Fig. 2, carapace, left valve lateral view, $\times 50$; Fig. 5, carapace, oblique dorsal view, $\times 46$; NHMOS13564. Bromide Formation. Fig. 3. Baltonotella circulantis (Harris, 1957). Carapace, right valve lateral view; overreach of left valve over the right valve dorsally is clearly visible, $\times 67$; NHMOS13565. Bromide Formation. Fig. 4. Baltonotella circulantis (Harris, 1957). Right valve, internal oblique lateral view; showing marked contact groove adjacent valve margin, $\times 58$; LEIUG112088. Edinburg Formation. Figs 6, 8. Baltonotella elegans (Harris, 1957). Carapace, oblique dorsal and left valve lateral views respectively, $\times 84$; MCZ4574. Oil Creek Formation. Figs 7, 10, 12, 13. Baltonotella elegans (Harris, 1957). Figs 7, 10, carapace, right valve lateral and ventral (stereo-pair) views respectively, $\times 39$; Fig. 12, anterior view, $\times 42$; Fig. 13, close-up of marginal structures, $\times 200$; NHMOS13637. Oil Creek Formation. Figs 9, 11. Baltonotella parsispinosa (Kraft, 1962). Carapace, right valve lateral and dorsal views respectively, $\times 35$; IGR5806. Edinburg Formation. Fig. 14. Baltonotella parsispinosa (Kraft, 1962). Carapace, close-up of marginal structures (left valve posterior), $\times 65$; FSL575056. Bromide Formation. 


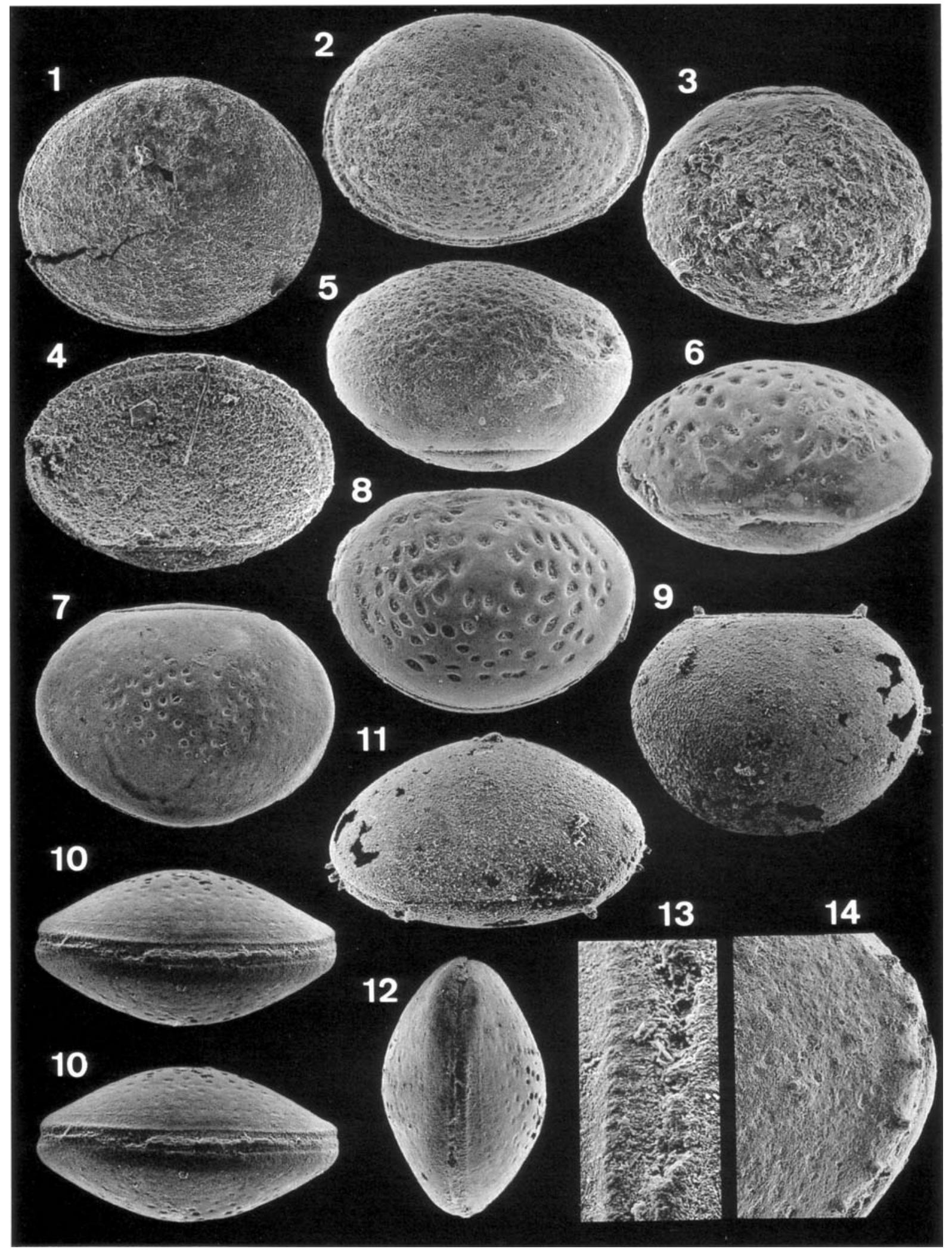

Plate 1 
2). Ornamentation is often dependant on preservation. Silicified valves of Baltonotella circulantis (= Aparchites suborbicularis Kraft, 1962) from Virginia are smooth (Pl. 1, fig. 1), whereas larger (adult and large juvenile) valves from Oklahoma (Pl. 1, fig. 2) and Kentucky (Warshauer \& Berdan 1982, pl. 10, figs $12-15$ ) are distinctly punctate.

\section{Features of the valve margin}

Ventral valve overlap and associated features. Aparchitids characteristically have specialized structures situated externally at the junction between the lateral and ventral valve surfaces. The larger right valve overlaps the left valve and the overlap contact is generally straight (Pl. 1, fig. 10). A lappet (or frill) of the right valve overreaches the (often flattened) ventral surface of the smaller left valve (Pl. 2, figs 9,10 ). Generally the left valve appears to prevent the right valve from excessive overlap by having a series of denticles (see Recent homologues in Vannier, 1990), sometimes situated on a low ridge, or less commonly by thickenings, which are situated at the junction between the lateral and ventral valve surfaces (Pl. 1, figs 13, 14; Pl. 2, figs 6, 9-11). Because of their small size, such structures are not always obvious in thin section. Excessive overlap is also prevented by a contact groove in the right valve, against which the overlapped portion of the left valve abutts (Pl. 1, fig. 4; see also Kraft, 1962, pl. 2, fig. 7; pl. 3, fig. 8). The overlap contact can also appear sinuous, with the larger right valve having a bow-shaped lappet ( $\mathrm{Pl}$. 2, fig. 8). Again, excessive overlap is prevented by denticles or thickenings of the left valve and by the presence in the right valve internally of a contact groove (see Vannier, 1990, figs 2, 3). The overlapping portion of the right valve (the frill or lappet) is usually demarcated from the ventral valve surface of the right valve by a groove or bend (Pl. 1, fig. 10; Pl. 2, figs 11, 14), or may be situated in a distinct channel (Pl. 2, fig. 7). Sometimes denticles are also situated on the right valve either at the junction between the lateral or ventral valve surfaces or sometimes within the demarcating groove of the lappet. The function of these structures is not clear.

In thin section Kraft (1962, fig. 7c, i, j) illustrated the overlap of two aparchitid ostracods (Aparchites fimbriatus and Aparchites suborbicularis $=B$. circulantis). In Kraft's illustrations the lappet of the right valve overlaps the flattened ventral surface of the left valve. The margin of the left valve is received internally by a shallow contact groove in the right valve formed by a marked thickening of the valve. The same features are evident in thin sections of aparchitid species from the Simpson Group (Pl. 4, figs 1, 2, 9, 10, 18; see also Fig. 5 D, E, G, H). The thickening of the right valve has marked relief in some species ( $\mathrm{Pl}$. 4, fig. 18) and forms a boss-like structure situated at some distance from the extreme tip of the right valve ventral margin (Pl. 4 , figs 16,18$)$. This is in contrast to schmidtellids where the contact groove of the overlapping valve, situated virtually at the ventral margin, is formed by a slight concavity in the valve and not by any related valve thickening (see Pl. 4, fig. 11). For this reason the degree of overlap in aparchitids is generally much greater than in schmidtellids (see Fig. 5, compare D, E, G, H with $\mathrm{M}, \mathrm{P}$ ). In B. circulantis (see Pl. 4, fig. 16) the thickened margin of the left valve appears to enclose a 'hollow' area indicated by dark, possibly organic material. Similarly, the thickened margin of the right valve which forms the contact groove also encloses a 'hollow' space. A third 'hollow' area lies adjacent to the external marginal sculpture of the left valve. The significance of these features is unknown. They may be artefacts, though those of the left valve in particular resemble a calcified inner lamella (see also Kraft, 1962, fig. 7j). None of the other aparchitids investigated have structures resembling a calcified inner lamella.

Hinge contact. Thin sections also clearly illustrate the nature of the dorsal contact. In the simplest case both valves meet at approximately the same height dorsally ( $\mathrm{Pl}$. 4, fig. 6) and the contact of the valves at the hinge appears to be simple (see Fig. 5 B). Commonly, particularly in the genus Baltonotella, the smaller left valve overreaches the larger right valve dorsally and may be strongly thickened adjacent the hinge (PI. 4, figs 1, 5, 13). More rarely, complicated arrangements exist in which the hinge of the left valve clearly has a groove into which the modified margin of the right valve interlocks (Pl. 4, fig. 17; see also Fig. 5 A). Again the margin of the left valve adjacent the hinge is thickened, probably to strengthen the contact.

\section{MORPHOLOGY OF SCHMIDTELLIDAE}

Schmidtellids are also well represented in the middle Ordovician of North America (Fig. 3). Several genera occur in the Simpson Group including Punctoschmidtella (Pl. 3, figs $2,3,5,7,8,10 ; \mathrm{Pl} .4$, figs $4,8,12$ ) and two species

\section{Explanation of Plate 2}

Aparchitidae. All specimens are from the Simpson Group, middle Ordovician, Oklahoma, USA. Figs 1, 3, 6. Hyperchilarina nodosimarginata Harris, 1957. Figs 1, 3, carapace, left valve lateral and oblique lateral views respectively, $\times 57$; Fig. 6 , close-up of marginal structures, $\times 100$; NHMOS13562. Bromide Formation. Figs 2, 5, 8. Hyperchilarina ovata Harris, 1957. Carapace, left valve lateral, oblique lateral and ventral (stereo-pair) views respectively, $\times 45$; MCZ4511. Tulip Creek Fomation. Figs 4, 7. 'Leperditella' subcygnoides Harris, 1957. Carapace, left valve lateral and oblique lateral (stereo-pair) views respectively, $\times 42 ;$ NHMOS13569. Oil Creek Formation. Figs 9, 10. Hyperchilarina nodosimarginata Harris, 1957. Fig. 9, Carapace, posterior view, $\times 90$; Fig. 10, nature of overlap and ventral structures, $\times 230$; FSL575055. Bromide Formation. Fig. 11. Saccelatia millipunctata (Ulrich, 1892). Carapace, close-up of ventral structures (sterco-pair); the overlapping portion of the right valve (bottom) is clearly demarcated from the ventral valve surface by a groove, $\times 280$; FSL575054. Bromide Formation. Figs 12, 14. Saccelatia millipunctata (Ulrich, 1892). Carapace, left valve lateral and oblique lateral views respectively, $\times 37 ;$ MCZ4507. Bromide Formation. Fig. 13. 'Leperditella' subcygnoides Harris, 1957. Carapace, dorsal view, $\times 40$; LEIUG112131. Oil Creek Formation. 


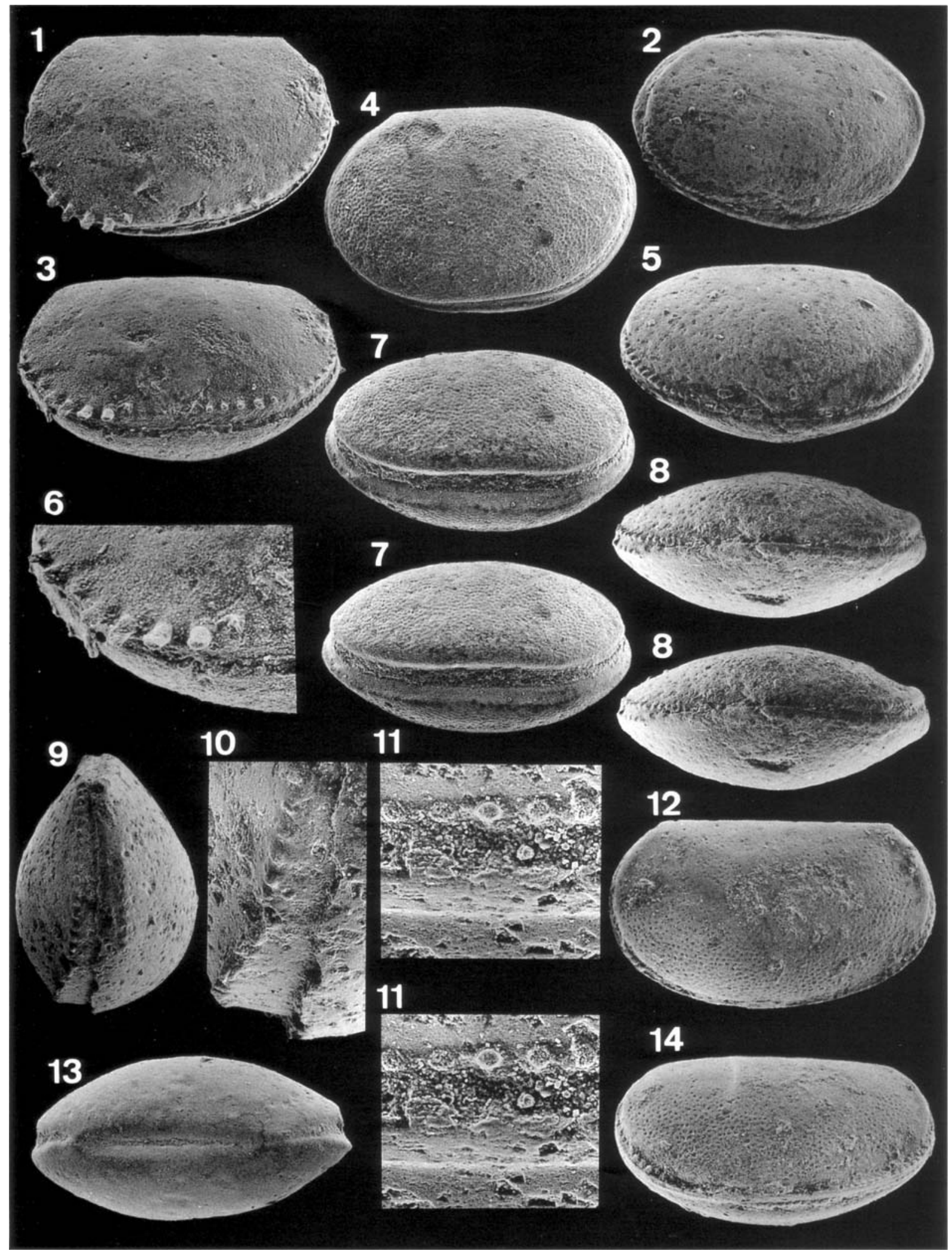

Plate 2 

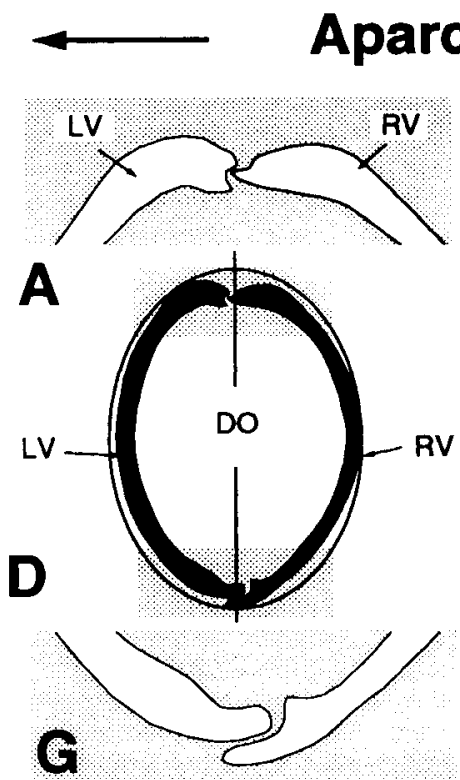

Baltonotella

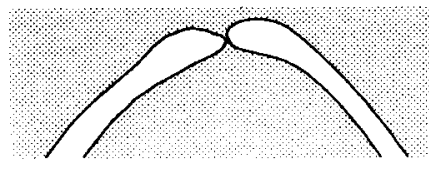

B

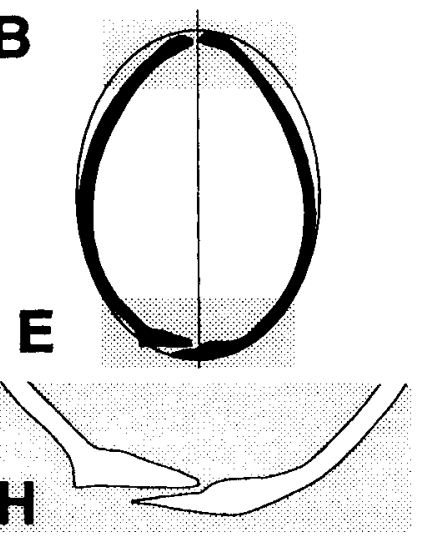

Hyperchilarina

\section{Jaanussoniidae}

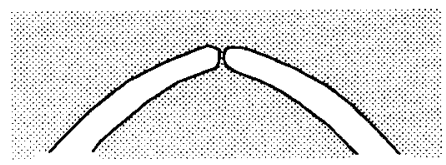

c

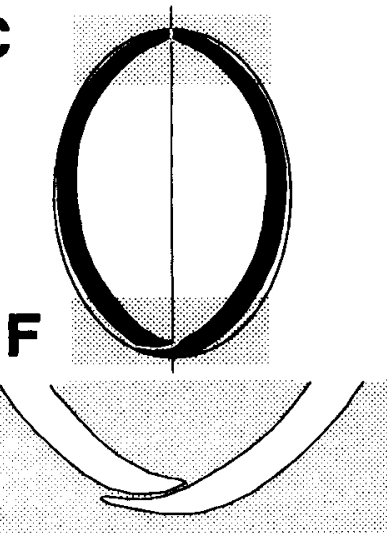

Jaanussonia

\section{Schmidtellidae}

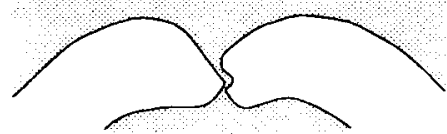

$\mathbf{J}$

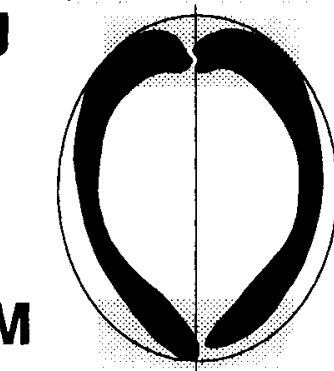

$\mathbf{P}$

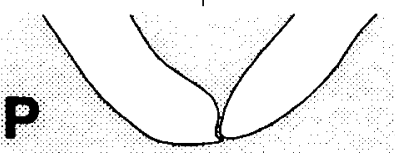

Gen. nov.

\section{Leperditellidae?}

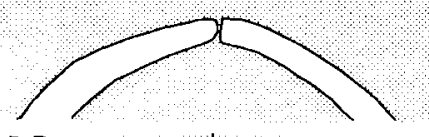

$\mathbf{K}$

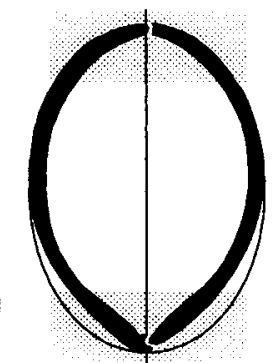

Q

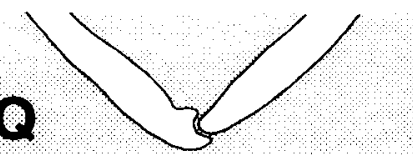

Kayina
Paraparchitidae

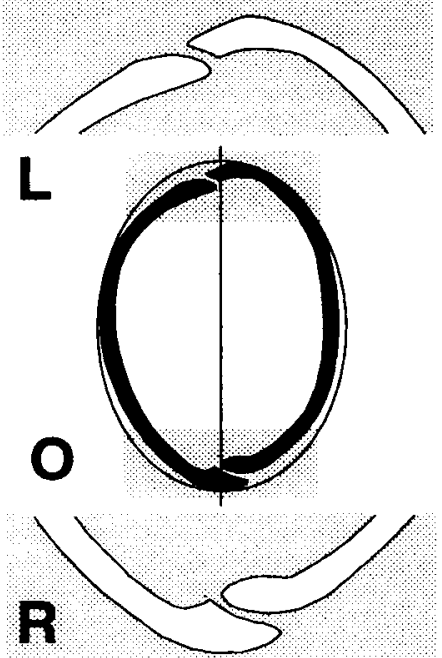

Paraparchites

Fig. 5. Morphology in transverse thin section of the dorsal valve margin (top), carapace (middle) and ventral valve margin (bottom) of selected ostracods. LV, left valve; RV, right valve; DO, domicilium. Ellipses enclosing the carapaces are used to emphasize shape. All illustrations have the left valve on the left side. 
referable to new genera ('Paraschmidtella' umbopunctata of Harris, 1957; Pl. 3, figs 1, 4, 6; Pl. 4, figs 3, 7, 11; and 'Schmidtella' minuta of Harris, 1957; Pl. 3, figs 9, 12; Pl. 4, figs 19,20 ). In the Simpson Group schmidtellids are most common in the Oil Creek Formation. Large (adult) specimens occur in profusion but, possibly owing to preservational or palaeoenvironmental factors, smaller specimens (juveniles) are less common.

\section{Geometry and general carapace morphology}

Carapace shape. In lateral view the carapace appears subcircular or subovate (Pl. 3, figs 1, 3, 5, 9). Because of the marked marginal flattening of the lateral surfaces from a ventral or dorsal aspect the valves appear like domes with a rim (Fig. 2, illustrations 4B-D).

Dorsal features. Schmidtellidae are often strongly umbonate making the dorsum distinctly epicline (Pl. 3, figs 2, 5; Pl. 4, figs 14, 19). In thin section the marked bend between the lateral and dorsal surfaces is very obvious and the valves are thicker at this point (Pl. 4, figs 3, 4, 7, $8,14,19)$. Mid-dorsally the valve is often strongly inflated to form a broad ridge or raised area which may also be strongly punctate (Pl. 3, figs 1, 3, 4, 6). The inner umbonal surfaces adjacent to the hinge may also have nodes (see Berdan, 1988, p. 289).

Marginal flattening. The valves are generally thick ( $\mathrm{Pl} .4$, figs 3, 4; see also fig. 5) and show strong marginal flattening or furrowing (Pl. 3, figs 1, 3, 5, 8, 9, 12). The flattening or furrowing can be continuous around the entire free margin but more commonly is restricted to the anterior and posterior margins. It may be more pronounced anteriorly (see Fiorello asymmetricus Berdan, 1988), posteriorly (Punctoschmidtella; Pl. 3, fig. 3) and/or differ in degree of development between the left and right valves (see Pl. 3, figs 1,6). Generally it is better developed on the right valve (Williams \& Vannier, 1993b).

Ontogeny. Berdan (1988, p. 288) noted that in juveniles of Punctoschmidtella species ( $P$. major) the umbo was less well developed. In juveniles of Punctoschmidtella in the Simpson Group the overall carapace shape is very similar to that of adults (compare PI. 3, figs 7, 5, juvenile and adult of $P$. pauciperforata respectively). Punctation is generally well developed, and a smooth (adductor muscle) spot can also be identified on juvenile valve surfaces.

\section{Domiciliar features}

Sulcation. Berdan (1988, p. 287), in discussing the characteristics of the Schmidtellidae recognized the existence in some species of an internal adductorial ridge (= sulcament of Berdan, 1988; see Fig. 2, illustration 8A). In species from the Simpson Group an adductorial ridge is generally not observed except in 'Schmidtella' minuta, where the valves appear to be slightly thickened midway between dorsal and ventral (see Pl. 4, figs 19, 20). At least one species from Oklahoma considered by Berdan (1988, p. 287) to be a schmidtellid, has a distinct sulcus (Pl. 3, fig. 8). Berdan $(1988$, p. 288,290$)$ also noted the presence of internal muscle scars in species of Punctoschmidtella and Fiorello from Utah; an exterior (adductorial) muscle spot commonly occurs in many schmidtellids ( $\mathrm{Pl}$. 3, figs $11,13,14)$. Several of the species referred to Schmidtella by Harris (1957: 'Schmidtella' asymmetrica, pl. 5, figs 1a-c; 'Schmidtella crassimarginata' sensu Harris, pl. 4, figs 1a-c; 'Schmidtella' excavata, pl. 4, figs 2a, b, 3; 'Schmidtella brevis' sensu Harris, pl. 4, figs 10a-c) include dimorphic forms which have strong internal sulcament and do not belong in the Schmidtellidae.

\section{Extradomiciliar features}

Ornamentation. This commonly comprises fine or coarse punctation (Pl. 3, figs 11, 3 respectively). Punctae are not concentrically arranged, but a smooth, subcentral (adductor muscle) spot is often evident.

\section{Features of the valve margin}

Ventral valve overlap. By contrast to the Aparchitidae in the Schmidtellidae the left valve is larger and overlaps the right valve (see Figs 1,5). The overlap contact between the valves is always straight and the overlapped portion of the right valve is received by a contact groove in the left valve (Pl. 3, fig. 10; see also Berdan 1988, pl. 3, fig. 16). Unlike in aparchitids the contact groove is situated very close to the ventral valve margin and is formed from a shallow concavity in the valve ( $\mathrm{Pl}$. 4, figs $11,12,15,20$ ). The degree of valve overlap is therefore much less than in aparchitids (Fig. $5 \mathrm{M}, \mathrm{P}$ ). Likewise there are no ridges, channels or denticles present at the junction between the lateral and ventral valve surfaces, although marked flattening of the ventral surface occurs in the right valve of some schmidtellids (Pl. 3, fig. 12; Pl. 4, fig. 20). Generally the total thickness of the left valve increases towards the ventral margin.

Hinge contact. In the simplest case the two valves meet at the hinge without any apparent modification (Pl. 4, fig. 19). However, the extreme dorsal margin of the left valve may form a narrow projection which interlocks with a broad concavity in the right valve (Pl. 4, fig. 8). Similar features are also recorded in aparchitids. More complicated arrangements exist in which a distinct ridge situated on the left (P1. 4, fig.14; Fig. 5 J, M) or right valve (Pl. 4, fig. 7) interlocks with a narrow groove in the opposing valve.

\section{THE GENUS KAYINA}

Although recorded from the middle Ordovician of Northern Europe (Schallreuter, 1971), jaanussoniid leiocopes in the middle Ordovician of North America have only been documented from the Bromide Formation of the Simpson Group, where the genus Kayina (originally described by Harris, 1957) was referred to the Jaanussoniidae by Schallreuter (1971). Two species of Kayina are present in the Bromide Formation ( $K$. hybosa, the type-species, and $K$. porosa; see Harris, 1957) but only a small number of adult and juvenile specimens of these species are known. Kayina shares with other jaanussoniids the development of a distinct posterodorsally situated node (hollow in jaanussoniids; see Vannier, 1988), occurring only on the left valve (Fig. 6). 


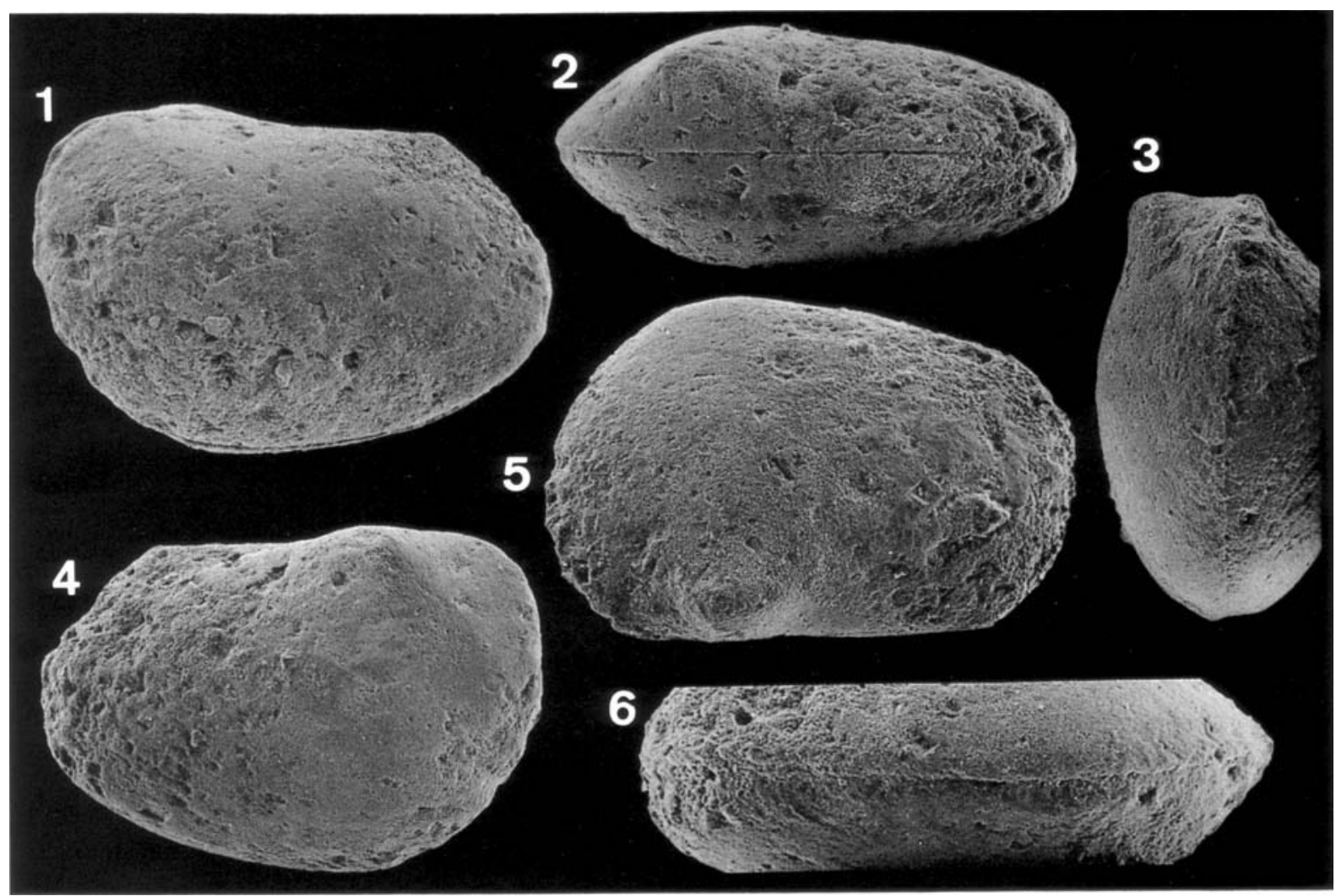

Fig. 6. Morphology of Kayina hybosa Harris, 1957, from the Bromide Formation, middle Ordovician, Oklahoma, USA. 1, 2, 4. Carapace, MCZ4530a: right valve lateral, dorsal and left valve lateral views respectively, $\times 57.3,5,6$ : Carapace NHMOS13571. 3, posterior view, 67; 5, oblique dorsal view, $\times 63 ; 6$, close-up of ventral structures, $\times 83$.

However, Kayina does not conform to typical jaanussoniid morphology (see Williams \& Vannier, 1993a; also compare with Fig. $1 \mathrm{C}, \mathrm{F}$ ). European Ordovician jaanussoniids (see Vannier, 1988, 1990) have typical aparchitacean morphology, in lateral view appearing subcircular to amplete equilateral and in ventral or dorsal view having convex dome-like valves. By contrast Kayina has a typical leperditellid outline with the width and height of the carapace increasing posteriorly (Fig. 6). Additionally in Jaanussonia, the nominate genus for the Jaanussoniidae, the right valve overlaps the left valve (see Vannier, 1988). In Kayina however, the left valve overlaps the right valve in typical leperditellid fashion (see Fig. $5 \mathrm{~N}$ ). Untypically for jaanussoniids, Kayina shows very slight valve overlap; the smaller right valve fitting into a shallow groove at the internal margin of the left valve (Fig. $5 \mathrm{Q}$ ). As suggested by Berdan (1988, p. 287) Kayina appears closely related to the palaeocope Leperditella.

\section{INNER LAMELLA}

With the exception of $B$. circulantis there is no evidence of a calcified inner lamella in any of the specimens observed in thin section (see also Gramm, 1984, pl. 3, figs 10, 11). Although clearly thickened in areas near the contact margin and hinge area, no bilamellar features (Gramm, 1984, 1988; Adamczak, 1991, figs 3, 4) or remains of a line of concrescence were recognized within the shell. The basic structure of the carapace integument described by Okada

\section{Explanation of Plate 3}

Schmidtellidae. All specimens are from the Simpson Group, middle Ordovician, Oklahoma, USA. Figs 1, 4. 'Paraschmidtella' umbopunctata Harris, 1957. Right valve lateral and dorsal views respectively, $\times 53$; MCZ4561. Oil Creek Formation. Figs 2, 5. Punctoschmidtella pauciperforata (Harris, 1957). Fig. 2, carapace, close-up of dorsal, $\times 70$; Fig. 5, carapace, right valve lateral view, $\times 54$; MCZ4550. Oil Creek Formation. Fig. 3. Punctoschmidtella? multicavata (Harris, 1957). Left valve lateral view (stereo-pair), $\times 43$; MCZ4548. Oil Creek Formation. Fig. 6. 'Paraschmidtella' umbopunctata Harris, 1957. Left valve lateral view, $\times 50$; MCZ4562. Oil Creek Formation. Fig. 7. Punctoschmidtella pauciperforata (Harris, 1957). Carapace, right valve lateral view, $\times 75$; FSL575053. Oil Creek Formation. Fig. 8. Punctoschmidtella? reticulata (Harris, 1957). Right valve lateral view, $\times 43$; MCZ4559. Oil Creek Formation. Figs 9, 12. 'Schmidtella' minuta Harris, 1957. Carapace, right valve lateral and oblique lateral views respectively, $\times 65 ;$ MCZ4543. Bromide Formation. Fig. 10. Punctoschmidtella pauciperforata (Harris, 1957). Left valve, internal lateral view, $\times 60$; FSL575051. Oil Creek Formation. Figs 11, 13, 14. 'Macronotella' mcgeheei Harris, 1957. Figs 11 , 14, left valve lateral and oblique lateral views respectively, $\times 48$; Fig. 13, close-up of muscle spot, $\times 110$; MCZ4573. Oil Creek Formation. 


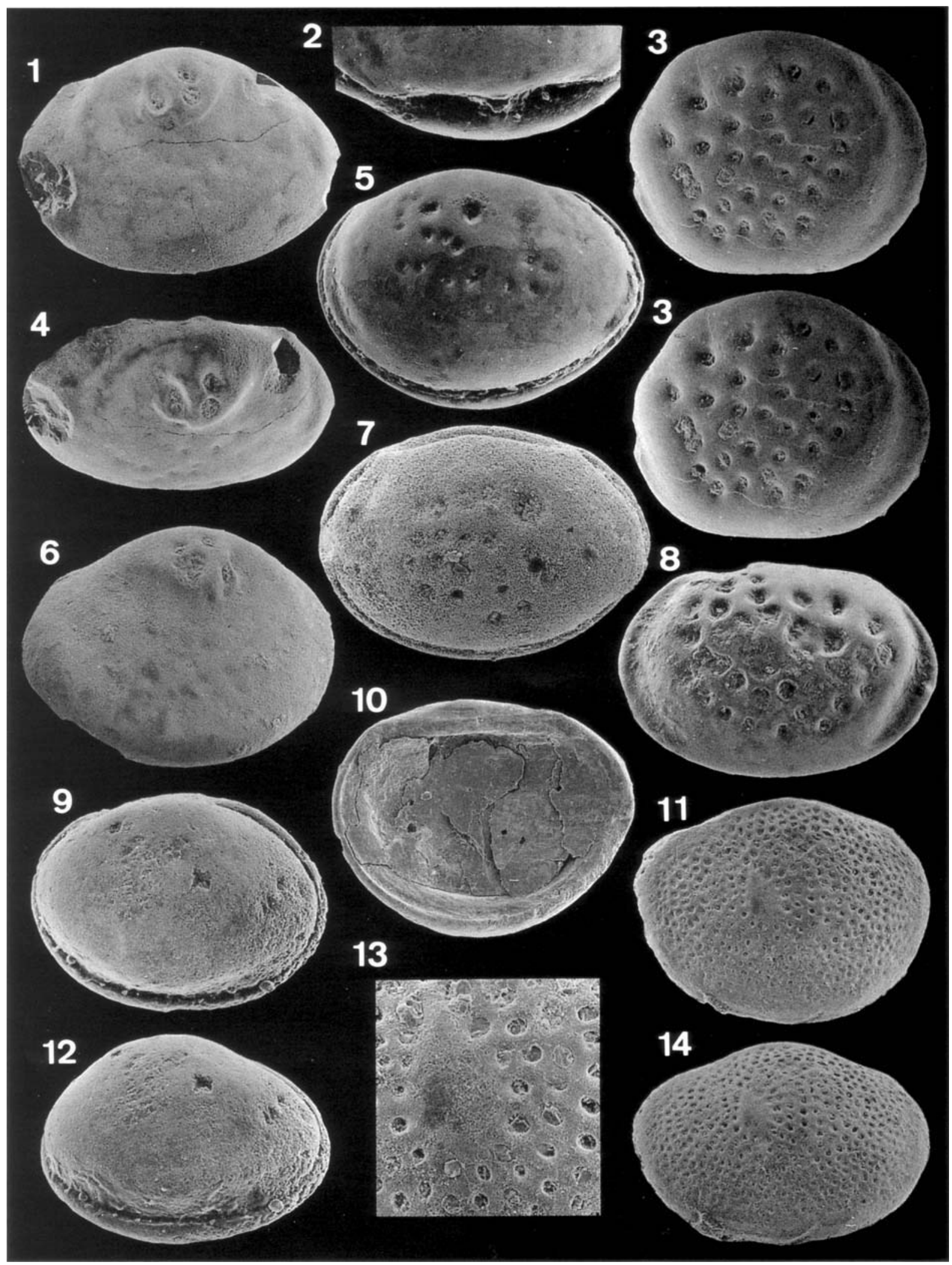

Plate 3 
(1982; epicuticle, procuticle, epidermal cells in both outer and inner lamella) from Recent podocopid species is likely to be applicable to most extant and extinct ostracods, including Lower Palaeozoic schmidtellids and aparchitids. If so, the procuticle of the inner lamella was probably not calcified in Ordovician aparchitids and schmidtellids and therefore not preserved in the fossil record. The external thickenings of the shell are interpreted herein as positive features of the calcified procuticle of the outer lamella; they seem to occur in places where the carapace needed to be strengthened (ventral contact, near ligament attachment). The internal thickenings observed on the inner surface of the valves near the ventral contact margin may be the attachment area of a thin, flexible non-calcified inner lamella, similar to the vestment (see Kornicker, 1969) of Recent ostracods.

\section{RELATIONSHIPS OF THE APARCHITIDAE, JAANUSSONIIDAE AND SCHMIDTELLIDAE}

Berdan (1988), primarily based on absence of sulcation, considered the Schmidtellidae to be Leiocopa and to belong to the Superfamily Aparchitacea. However, the morphological features of typical Aparchitacea (jaanussoniids and aparchitids) show important differences from schmidtellids. Principally jaanussoniids and aparchitids are relatively thin shelled and have the right valve overlapping the left valve (Fig. 5 D-I). The degree of overlap can be marked and in the Aparchitidae the contact groove of the right valve is situated some distance from the valve margin. Aparchitaceans show no marginal flattening of the valves and are characterized by dorsal or ventral valve modifications usually limited to the left valve. By contrast, schmidtellids are thick shelled with the left valve overlapping the right valve. The degree of overlap is slight with the contact groove of the left valve situated near to the valve margin (Fig. $5 \mathrm{P}$ ). In addition schmidtellids lack the valve modifications which are so characteristic of jaanussoniids and aparchitids. These fundamental differences indicate that the Schmidtellidae should be classified separately from the Aparchitacea. In addition, many schmidtellids closely resemble leperditellids (see also discussion in Warshauer \& Berdan, 1982). Leperditellids (palaeocopes) are likewise thick shelled, have the left valve with a distinct contact groove for receiving the overlapped portion of the right valve and show similar flattening or furrowing of the valve margins. The relationship of the Schmidtellidae to the Leperditellidae needs to be clarified, particularly by investigation of valve margin morphology in the Leperditellidac. It is possible that the Schmidtellidae are more closely related to leperditellacean palaeocopes than to leiocopes.

The paraparchitaceans and pseudoparaparchitaceans form a vast group of smooth, non-sulcate, subovoid ostracods with external features similar to aparchitaceans. They occur worldwide from the Devonian through to the Permian and are well represented in North America (Sohn, 1971a, $b$, 1983). The question of their origin has not been addressed. Paraparchitaceans differ from aparchitaceans in having a ventral left over right valve overlap (Fig. $5 \mathrm{O}, \mathrm{R}$ ). Although neglected in the revision of the group (Sohn, 1971 $a, b$ ), this constant pattern constitutes a common feature shared by all paraparchitaceans. Paraparchitaceans show variation in size and shape of adult carapaces, interpreted (Sohn, 1971a, p. 3; Abushik et al., 1990, fig. 7) as possible sexual dimorphism. No dimorphic features of any type are so far recognized in aparchitids or jaanussoniids.

The presence of a calcified inner lamella in paraparchitaceans, claimed by Sohn $(1971 a)$ as an indicator of podocopid affinities, is not clearly demonstrated either from sections or from views of single valves (e.g. Shishaella, Sohn, 1971b, pl. 9, fig. 16) and is therefore debatable. Paraparchites humerosus (tranverse section, Sohn, 1971a, pl. 2, fig. 17) shows internal thickenings of the shell on both valves at the contact margin but no distinct calcified inner lamella. It is also true for pseudoparaparchitaceans as exemplified by Microparaparchites (Sohn, 1983, pl. 3, fig. 24). Gramm (1984, pl. 10, figs 6, 7) shows bilamellar structures in Paraparchites suborbiculatus from the Carboniferous, where the shell develops inwards a dark, probably organic rich layer close to the ventral contact margin. Even though this layer is a possible inner lamella, it is extremely faint in comparison with the calcified inner lamella of true podocopes (Schallreuter, 1979), which exhibit a large vestibule. The origin of paraparchitaceans from the aparchitacean lineage (during the Devonian?) is a strong possibility.

\section{DISTRIBUTION OF APARCHITIDAE AND SCHMIDTELLIDAE IN THE MIDDLE ORDOVICIAN OF NORTH AMERICA Stratigraphic distribution}

Aparchitids and schmidtellids are widespread and often abundant in middle Ordovician sequences of North America (Fig. 3). Based primarily on the faunas of the Simpson

\section{Explanation of Plate 4}

Thin sections. Left valves of specimens are orientated on the left. All specimens are from the Simpson Group, middle Ordovician, Oklahoma, USA. Figs 1, 5, 9. Baltonotella parsispinosa (Kraft, 1962). Fig. 1, carapace, $\times 32$; Figs 5, 9, dorsal and ventral views respectively, $\times 75$; FSL575066. Bromide Formation. Figs 2, 6, 10. Hyperchilarina nodosimarginata Harris, 1957. Fig. 2, carapace, $\times 32$; Figs 6 , 10, dorsal and ventral views respectively, $\times 75$; FSL575065. Bromide Formation. Figs 3, 7, 11. 'Paraschmidtella' umbopunctata Harris, 1957. Fig. 3, carapace, $\times 44$; Figs 7, 11, dorsal and ventral views respectively, $\times 60$; FSL575070. Oil Creek Formation. Figs 4, 8, 12. Punctoschmidtella pauciperforata (Harris, 1957). Fig. 4, carapace, $\times 44$; Figs 8, 12, dorsal and ventral views respectively, $\times 60$; FSL575069. Oil Creek Formation. Figs 13, 16. Baltonotella circulantis (Harris, 1957). Dorsal and ventral views respectively, $\times 95$; FSL575062. Bromide Formation. Figs 14, 15. 'Schmidtella affinis' Ulrich, 1892 sensu Harris, 1957. Dorsal and ventral views respectively, $\times 60$; FSL575067. Bromide Formation. Figs 17, 18. Baltonotella ovalis (Harris, 1957). Dorsal and ventral views respectively, $\times 60$; FSL575064. Bromide Formation. Figs 19, 20. 'Schmidtella' minuta Harris, 1957. Dorsal and ventral views respectively, $\times 60$; FSL575068. Bromide Formation. 

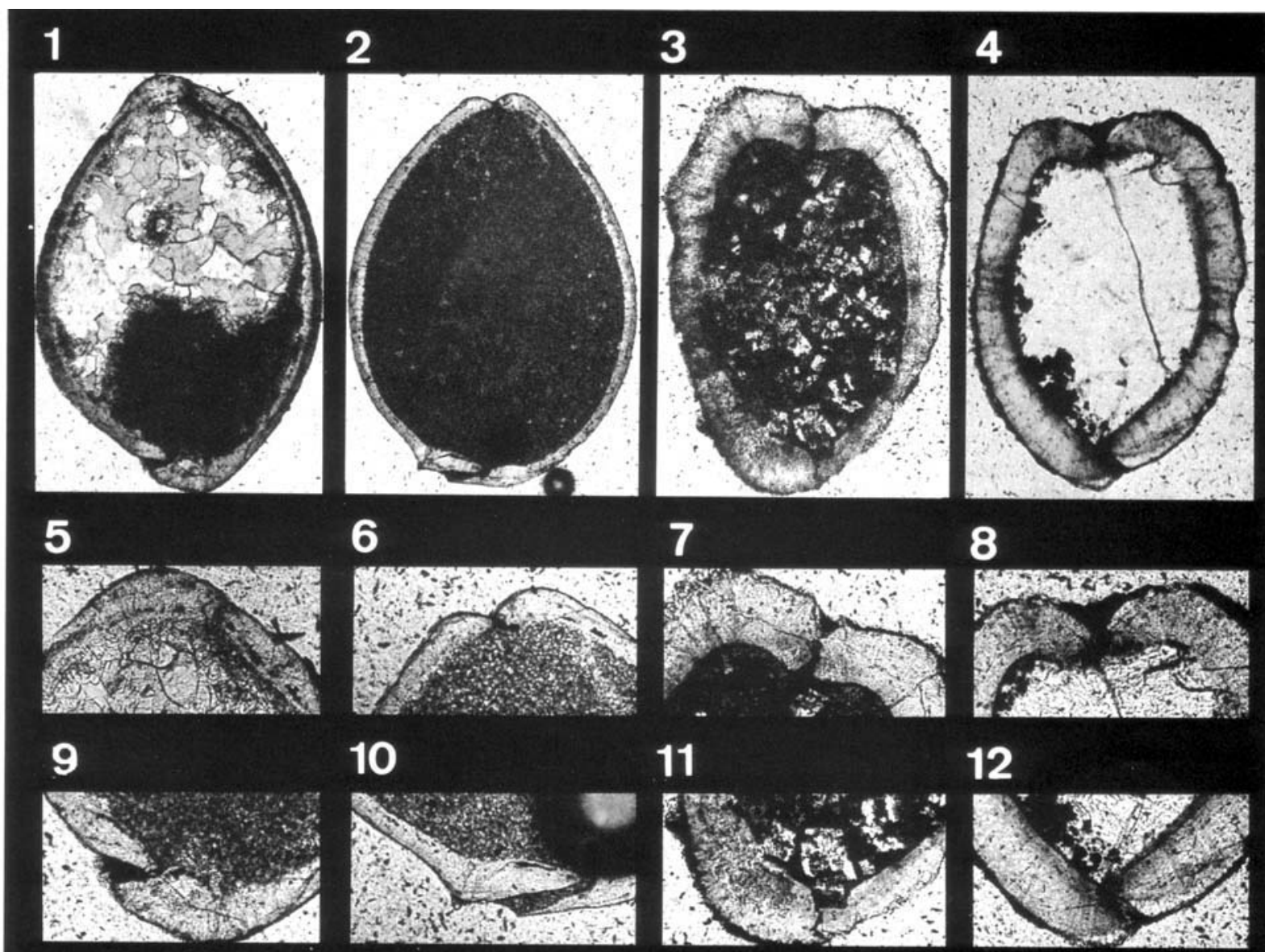

12

13

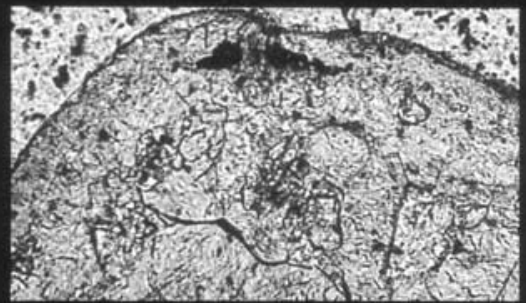

16

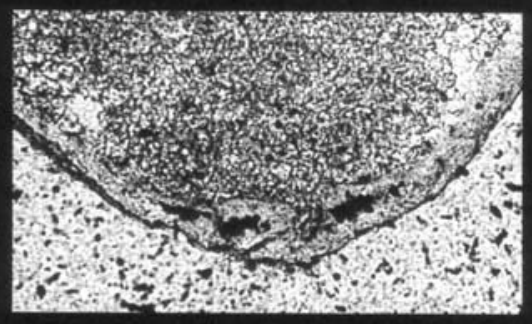

\section{4}

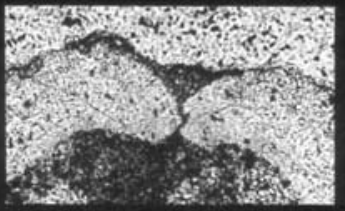

17

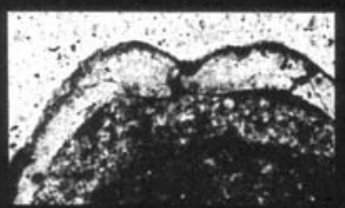

19

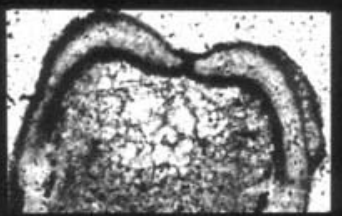

15

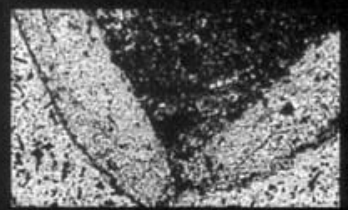

18

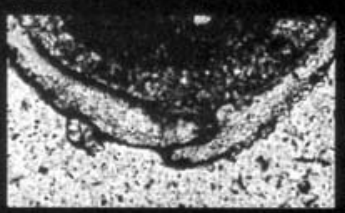

20

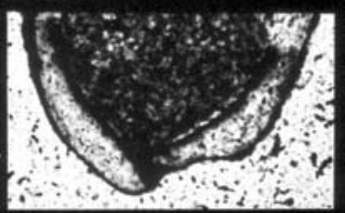

Plate 4 
Group, and by comparison with middle Ordovician ostracod faunas described from other North American sequences (e.g. Utah in Berdan, 1988; Virginia in Kraft, 1962; Kentucky in Warshauer \& Berdan, 1982; Minnesota in Swain et al., 1961) two apparently time stratigraphic groupings of aparchitids and schmidtellids can be recognized.

Early middle Ordovician. The early middle Ordovician Oil Creek Formation of Oklahoma (Whiterockian; conodont zones 3 and 4; see Sweet \& Bergström 1976) includes characteristic co-occuring schmidtellid species belonging to short ranging genera such as Punctoschmidtella pauciperforata (Pl. 3, figs 2, 5, 7, 10) and 'Paraschmidtella' (= new genus) umbopunctata (Pl. 3, figs 1, 4, 6). These schmidtellids are morphologically most similar to ostracods described from the early middle Ordovician Kanosh Shale and lower part of the Lehman Formation of Utah (Berdan, 1988, pls 3, 4) which are rich in species of the schmidtellid genera Fiorello and Punctoschmidtella. Correlation of these two sequences is also indicated by other ostracods (see Berdan, 1988). Although other sequences of a comparable age in North America have been inadequately studied for ostracods it is possible that abundant schmidtellids such as Punctoschmidtella and Fiorello (see Pl. 3) may characterize the early middle Ordovician.

Late middle Ordovician. The late middle Ordovician Bromide Formation of Oklahoma (late Whiterockianearly Mohawkian; conodont zones 5-6 to 7; see Sweet \& Bergström, 1976) contains a characteristic association of aparchitids including Baltonotella circulantis, B. parsispinosa and Hyperchilarina nodosimarginata which are very abundant and have ranges restricted to the Bromide Formation in Oklahoma. Faunas rich in these taxa are reported from the Edinburg Limestone of Virginia (Kraft, 1962; Aparchites parsispinosus and A. suborbicularis), the Lexington Limestone of Kentucky (Warshauer \& Berdan 1982; Brevidorsa strodescreekensis and Aparchites sp.) and Baffin Island, Canada (Silliman's Fossil Mount; Copeland, 1977; 'Aparchites' sp. cf. 'A.' fimbriatus and Leperditella sp.).

\section{Palaeoenvironmental distribution in the Simpson Group}

In the Simpson Group aparchitids and schmidtellids do not occur in deposits of very shallow marine aspect such as the Birdseye micrites of the Oil Creek, Mclish or Bromide formations (see sedimentological data of Longman, 1981, 1982; Fay et al, 1982). However, in sediments deposited in a marine subtidal setting they are diverse and numerically abundant. In the Oil Creek Formation schmidtellids are widespread in subtidal facies considered by Lewis (pers. comm.) to have been deposited in water depths of up to a maximum of $20 \mathrm{~m}$. Species such as $P$. pauciperforata commonly occur in such facies but are absent from birdseye micrites in the same Formation. Aparchitids such as $B$. elegans are also common in subtidal facies of the Oil Creek Formation.

In the Bromide Formation sedimentary facies representing subtidal deposition contain aparchitid species such as
S. millipunctata, $H$. nodosimarginata, $B$. circulantis and $B$. parsispinosa and schmidtellids such as 'Schmidtella' minuta in profusion. Longman $(1981,1982)$ estimated that in some areas of the depositional basin of the Bromide Formation (the Southern Oklahoma Aulacogen; see Shatski 1946) sedimentation depths of $80 \mathrm{~m}$ were achieved. As with the Oil Creek Formation aparchitids and schmidtellids do not occur in sediments thought to be the product of very shallow marine deposition (i.e. birdseye micrites) but are widespread in subtidally deposited normal marine sediments.

In the Simpson Group aparchitid and schmidtellid ostracods appear to occur exclusively in sediments indicative of subtidal deposition.

\section{Palaeoenvironmental distribution in North America}

Berdan (1988) added no palaeoenvironmental data to her description of faunas from the early middle Ordovician of Utah, which includes rich schmidtellid faunas like those of the Oil Creek Formation of Oklahoma. However, the associated ostracods and macrofauna (Berdan, 1988, p. 274-275) suggest that the Kanosh Shale and lower part of the Lehman Formation were deposited subtidally.

Similar aparchitid and schmidtellid faunas to those of the Bromide Formation are widely documented from other North American middle Ordovician sequences (see Fig. 3) but largely without reference to palaeoenvironment. However, Copeland (1982) in defining ostracod biofacies for the Lower Esbataottine Formation of Canada recognized that the occurrence of taxa he referred tentatively to Aparchites were characteristic of his deeper marine platform biofacies. Likewise it seems from the associated ostracods that aparchitid rich faunas in the middle Ordovician Edinburg Formation of Virginia (Kraft, 1962; pls 1,2) and the Decorah Shale of Minnesota (Swain et al., 1961; pls 46, 47) also occur in sediments subtidally deposited in normal marine shelf environments.

\section{ACKNOWLEDGEMENTS}

M. Williams gratefully acknowledges a Europe Fellowship from the Alexander von Humboldt Stiftung in Bonn, Germany carried out at the Université Claude Bernard, Lyon, France. Mr M. A. Miller (Amoco, Houston), Dr R. O. Fay (Oklahoma Geological Survey), Dr B. Webby (University of Oklahoma) and the Pletcher family (Davis, Oklahoma) provided invaluable help with fieldwork. Drs D. J. Siveter, R. J. Aldridge, C. G. Miller and Mr A. Swift (University of Leicester), and Dr R. Fortey (Natural History Museum, London) provided interesting discussions on taxonomic problems. Dr J. Berdan (Smithsonian Institution, Washington DC) is thanked for the loan of type material. Prof C. Babin, Mr P. Castelli and Mr G. Sirven are thanked for facilities and technical expertise at the Centre des Sciences de la Terre (URA 11-CNRS), Université Claude Bernard.

\section{Manuscript received April 1993 Manuscript accepted March 1994}




\section{REFERENCES}

Abushik. A. F., Ivanova, V. A. \& Sidaravichiene, N. V. 1990 Dictionary of terms. In Abushik, A. F. (Ed.), Practical manual on microfauna of USSR, Vol. 4. Paleozoic Ostracoda. [In Russian.]

Adamczak, F. J. 1991. Kloedenellids: morphology and relation to non-myodocopide ostracodes. Journal of Paleontology, 65: $255-267$.

Bauer, J. A. 1987. Conodonts and conodont biostratigraphy of the Mclish and Tulip Creek formations (middle Ordovician) of south central Oklahoma. Bulletin of the Oklahoma Geological Survey, 141: $1-58$.

Berdan, J. M. 1988. Middle Ordovician (Whiterockian) palaeocopid and podocopid ostracodes from the Ibex area, Millard County, western Utah. New Mexico Bureau of Mines \& Mineral Resources Memoir, 44: 273-301.

Chapman, F. 1901. On some fossils of Wenlock age from Mulde, near Klinteberg, Gotland. Annals and Magazine of Natural History, 38: 141-160.

Cooper, G. A. 1956. Chazyan and related brachiopods. Smithsonian Miscellaneous Collections, 127: 1-1245.

Copeland, M. J. 1965. Ordovician ostracoda from Lake Timiskaming, Ontario. Bulletin of the Geological Survey of Canada, 127: 1-52.

Copeland, M. J. 1974. Middle Ordovician ostracoda from southwestern District of Mackenzie. Bulletin of the Geological Survey of Canada, 244: 1-55.

Copeland, M. J. 1977. Ordovician Ostracoda, southeastern District of Franklin. Bulletin of the Geological Survey of Canada, 269: 77-97.

Copeland, M. J. 1982. Bathymetry of early middle Ordovician (Chazy) Ostracodes, Lower Esbataottine Formation, District of Mackenzie. Bulletin of the Geological Survey of Canada, 347: $1-39$.

Copeland, M. J. \& Bolton, T. E. 1977. Additional paleontological observations bearing on the age of the Lourdes Formation (Ordovician), Port au Port Peninsula, western Newfoundland. Geological Survey of Canada Paper, 77-1b: 1-13.

Decker, C. E. \& Merritt, C. A. 1931. The stratigraphy and physical characteristics of the Simpson Group. Bulletin of the Oklahoma Geological Sunvey, 55: 1-112.

Fay, R. O.. Grafham, A. \& Sprinkle, J. 1982. Measured sections and sampling localities. In Sprinkle, J. (Ed.), Echinoderm faunas from the Bromide Formation (middle Ordovician) of Oklahoma. University of Kansas Paleontological Contributions, Monograph, 1: $345-369$

Grahn, Y. \& Miller, M. A. 1986. Chitinozoa from the middle Ordovician Bromide Formation, Arbuckle Mountains, Oklahoma, USA. Neues Jahrbuch für Geologie und Paläontologie, Abteilung $B$, 172: 381-403.

Gramm, M. N. 1984. Vnutrennije structure rakovin paleozoisskikh ostracods, 1-72. Nauka, Leningrad. [In Russian.]

Gramm, M. N. 1988. The free margin contact structures in some 'palaeocopid' ostracods and their bearing on classification. In Hanai, T., Ikeya, N. \& Ishizaki, K. (Eds), Evolutionary biology of Ostracoda, its fundamentals and applications. 159-174, Proceedings of the 9th International Symposium on Ostracoda, Elsevier, Amsterdam.

Harris, R. W. 1931. Description of Microfauna. In Decker, C. E. \& Merritt, C. A. (Eds), The stratigraphy and physical characteristics of the Simpson Group. Bulletin of the Oklahoma Geological Survey, 55: 87-95.

Harris, R. W. 1957. Ostracoda from the Simpson Group. Bulletin of the Oklahoma Geological Survey, 75: 1-333.

Kay, G. M. 1940. Ordovician Mohawkian Ostracoda, lower Trenton Decorah fauna. Journal of Paleontology, 14: 234-269.

Kempf, E. K. 1986. Index and bibliography of marine Ostracoda 1: Index $A$. Sonderveröffentlichungen Geologisches Institut der Universität Köln, 50.

Kornicker, L. S. 1969. Relationship between the free and attached margins of the myodocopid ostracod shell. In Neale, J.W. (Ed.), The taxonomy, morphology and ecology of Recent Ostracoda. 109-135, Oliver \& Boyd, Edinburgh.
Kraft, J. C. 1962. Morphologic and systematic relationships of some middle Ordovician Ostracoda. Geological Society of America, Memoir, 86: 1-104.

Longman, M. W. 1981. Depostion of the Bromide Formation, Arbuckle Mountains, Oklahoma: ontogeny of an ancient carbonate shelf. Shale Shaker, 32: 1-18.

Longman, M. W. 1982. Depositional environments. In Sprinkle, J. (Ed.), Echinoderm faunas from the Bromide Formation (middle Ordovician) of Oklahoma. University of Kansas Paleontological Contributions, Monograph, 1: 17-30.

Neckaja, A. I. 1966. Ostrakody Ordovika i Siluria SSSR (semejstva Schmidtellidae, Rectellidae, Longisculidae i nekotorye novye vidy drugich semejstva). Trudy Vsesoyuznogo Neftyanogo NauchoIssledovatelskogo Geologo-Razvedochnoogo Instituta, Novaya Seriya, 251: 1-104. [In Russian.]

Okada, Y. 1982. Ultrastructure and pattern of the carapace of Bicornucythere bisanensis (Ostracoda, Crustacea). In Hanai, T. (Ed.), Studies on Japanese Ostracoda, 229-267. University Museum, University of Tokyo, Bulletin No. 20.

Ross, R. J. Jr., et al., 1982. The Ordovician System in the United States correlation chart and explanatory notes. International Union of Geological Sciences Publication, 12: 1-73.

Schallreuter, R. E. L. 1971. Asymmetrische ordovizische Ostrakoden. Neues Jahrbuch für Geologie und Paläontologie, Monatsheft, 4: $249-260$.

Schallreuter, R. E. L. 1973. Die Ostracodengattung Hyperchilarina und das Aparchites-Problem. Geologiska Föreningens i Stockholm Förhandlingar, 95: 37-49.

Schallreuter, R. E. L. 1979. Ordovician Podocope Ostracodes. In Proceedings of the 7 th international symposium on ostracodes. 25-28. Serbian Geological Society.

Shatski, N. S. 1946. The Great Donets Basin and the Wichita System: Comparative tectonics of ancient platforms. Izvestiya Akademii Nauk SSSR, Seriya Geologischeskaya, 6: 57-90.

Shaw, F. C. 1974. Simpson Group (middle Ordovician) trilobites of Oklahoma. Memoirs of the Paleontological Society, 6: 1-54.

Sohn, I. G. 1971a. New late Mississippian ostracode genera and species from northern Alaska. A revision of the Paraparchitacea. United States Geological Survey Professional Paper, 711A: 1-23.

Sohn, I. G. 1971b. Late Paleozoic ostracode species from the conterminous United States. A revision of the Paraparchitacea. United States Geological Survey Professional Paper, 711B: $1-15$.

Sohn, I. G. 1983. Ostracodes of the 'Winifrede Limestone' (Middle Pennsylvanian) in the region of the proposed Pennsylvanian System Stratotype, West Virginia. Bulletins of American Paleontology, 84, 316: 1-53.

Sprinkle, J. 1982. Echinoderm faunas from the Bromide Formation (middle Ordovician) of Oklahoma. University of Kansas Paleontological Contributions, Monograph, 1.

Swain, F. M. 1957. Early middle Ordovician ostracoda of the eastern United States, part 1: stratigraphic data and description of Leperditidae, Aparchitidae and Leperditellidae. Journal of Paleontology, 31: 528-570.

Swain, F. M., Cornell, J. R. \& Hanson, D. L. 1961. Ostracoda of the families Aparchitidae, Aechminidae, Leperditellidae, Drepanellidac, Eurychilinidae and Punctaparchitidae from the Decorah Shale of Minnesota. Journal of Paleontology, 35: 345-372.

Swartz, F. M. 1969. The Ordovician ostracode Aparchites whiteseavi Jones (1889) and problems of relationships. Journal of Paleontology, 43: 1237-1244.

Sweet, W. C. 1984. Graphic correlation of upper middle and upper Ordovician rocks, North American Midcontinent Province, U.S.A. In Bruton, D. L. (Ed.), Aspects of the Ordovician System. Palaeontological Contributions from the University of Oslo, 295: 23-35.

Sweet, W. C. \& Bergström, S. 1976. Conodont biostratigraphy of the middle and upper Ordovician of the United States Midcontinent. In Bassett, M. G. (Ed.), The Ordovician System. 121-151. University of Wales Press and the National Museum of Wales.

Ulrich, E. O. 1892. New lower Silurian Ostracoda, No. 1. American Geologist, 10: $263-270$. 
Ulrich, E. O. 1894. The Lower Silurian Ostracoda of Minnesota. Geological and Natural History Survey of Minnesota, 3: 2, 1892-1896 (1897): 629-693.

Vannier, J. 1988. On Jaanussonia unicerata Schallreuter. Stereo Atlas of Ostracod Shells, 15: 137-142.

Vannier, J. 1990. Functional morphology and mode of life of Palaeozoic leiocope ostracodes. Lethaia, 23: 103-112.

Warshauer, S. M. \& Berdan, J. 1982. Palaeocopid and podocopid ostracoda from the Lexington Limestone and Clays Ferry
Formation (middle and upper Ordovician) of central Kentucky. United States Geological Survey Professional Paper, 1066-H: $1-77$.

Williams, M. \& Vannier, J. 1993a. On Kayina hybosa Harris. Stereo Atlas of Ostracod Shells, 20: 41--44.

Williams, M. \& Vannier, J. 1993b. On Punctoschmidtella pauciperforata (Harris). Stereo Atlas of Ostracod Shells, 20: $45-48$. 